\title{
Illustrations, Figures, and Tables
}

\section{Illustrations}

8.1 Summerhouse residence in Norrtälje 193

8.2 Off-grid home in Norrtälje with well and septic tank 194

9.1 The new urban area My Dinh II 218

9.2 Land and water in the peri-urban village Van Phuc 218

9.3 Water supply plant in the new urban area Linh Dam 220

9.4 Wastewater treatment plant in the new urban area My Dinh II 220

9.5 Fishing pond in the peri-urban village Lai Xa 222

10.1 Impermeable cover in Florida's Super Region, 2011239

10.2 Arizona Sun Corridor Partnership and Joint Planning Advisory Council extents 243

10.3 Greater Orlando and Greater Tampa metropolitan areas overlapping Polk County 247

$12.1 \quad$ Greater Golden Horseshoe Greenbelt 286

12.2 Highway construction within the GGH Greenbelt 289

12.3 Campaign to stop Highway 413290

15.1 Different forms of environmental injustices 343

15.2a, 15.2b Private sector real estate markets have played an important role in implementing sustainability-as-density policies 346

15.3 Young adult residential locations in Vancouver coincide with high-density and transit-accessible locations 357 
x Illustrations, Figures, and Tables

\section{Figures}

7.1 Michigan total state and local taxes, 2015169

7.2 Sales and excise tax share of family income, $2015 \quad 170$

7.3 Personal income tax share of family income, 2015171

14.1 The Green Deal process 323

14.2 Haringey's multi-stakeholder retrofit network 332

\section{Tables}

2.1 Matrix of suburban infrastructures 53

2.2 The EJ\&E Railroad as suburban infrastructure 60

7.1 Households and vehicle characteristics by income, the Detroit region 163

8.1 Percentage of population connected to centralized water and wastewater systems in Stockholm County municipalities 192

10.1 Port concentration in the top eight states by freight volume 251

14.1 Comparison between the RetrofitWorks and the Smart Homes approaches 330

15.1 Young adults' commute distance as a function of demography 352

15.2 Young adults' commute mode as a function of demography 354 